\title{
ANALYSIS OF GOOD MANUFACTURING PRACTICE AT HOME INDUSTRY FOR CATFISH FLOSS IN PURWOSARI, KEDIRI REGENCY
}

\section{ANALISIS PENERAPAN CARA PRODUKSI PANGAN OLAHAN YANG BAIK PADA INDUSTRI RUMAH TANGGA PEMBUATAN ABON IKAN LELE DI DESA PURWOSARI KECAMATAN KANDAT KABUPATEN KEDIRI}

\author{
Susetyo Ilman Rosyadi ${ }^{1}$, Eddy Afrianto ${ }^{1}$, Achmad Rizal ${ }^{1}$, Rusky Intan Pratama ${ }^{1}$ \\ Program Studi Perikanan, Fakultas Perikanan dan Ilmu Kelautan, Universitas Padjadjaran Jalan Raya Bandung - \\ Sumedang Km 21 Jatinangor, Sumedang, Jawa Barat. Correspondence Author : ilmanros06@gmail.com
}

\begin{tabular}{|c|c|}
\hline INFO AR & B S T R A C T \\
\hline & \multirow[b]{2}{*}{$\begin{array}{l}\text { This study aims to study the application of Good Manufacturing Practice (GMP) at } \\
\text { home industry for catfish floss in Purwosari, Kediri Regency. This research was } \\
\text { conducted in May 2017, located in Purwosari Village Kandat Subdistrict Kediri } \\
\text { Regency and Fisheries Processing Laboratory of Padjadjaran University. Laboratory } \\
\text { testing was conducted at the Laboratory of Testing Services Faculty of Agricultural } \\
\text { Industrial Technology Padjadjaran University and Laboratory of Control and } \\
\text { Testing of Quality of Fishery Products of East Java. The method used is survey, by } \\
\text { observing directly the flow of process for making catfish floss. Organoleptic testing } \\
\text { with } 20 \text { semi-trained panelists. Based on the results of the research, the process of } \\
\text { making catfish abon is the acceptance of materials, washing I, weeding, washing II, } \\
\text { steaming, shredding, mixing, frying, slicing, packaging, storage and loading (no } \\
\text { pressing process). Microbiological test (ALT Aerob: } 1.7 \text { x } 10^{2} \text { Colonies / g, E. coli: } \\
<3 \text { APM / g, Staphyloccocus aureus: <10 Colonies / g, Salmonella negative), } \\
\text { chemical test (protein: } 40.55 \% \text { and air water: } 4.83 \% \text { ) and organoleptic test }(7,2) \\
\text { according to SNI specification. Catfish floss is good in the specified quality } \\
\text { specification, but there needs to be improvement in the processing process so that } \\
\text { catfish floss can provide quality assurance and safety to the consumer. }\end{array}$} \\
\hline $\begin{array}{l}\text { Kata kunci: } \\
\text { Catfish Fluss, Good } \\
\text { Manufacturing Practice, } \\
\text { Process, Quality }\end{array}$ & \\
\hline
\end{tabular}

\section{PENDAHULUAN}

Berdasarkan data dari Dinas Perikanan Jawa Timur, Kabupaten Kediri adalah daerah yang memiliki potensi hasil perikanan dengan kemampuan produksi ikan lele sebesar 112.705,9 ton pada tahun 2015 atau sebesar 8,86\% dari total produksi Provinsi Jawa Timur. Kemampuan produksi tersebut dapat diserap dengan adanya Kelompok Pengolahan dan Pemasar Ikan (Poklahsar) Kabupaten Kediri.

Salah satu Poklahsar yang menjadi percontohan di Kabupaten Kediri berada di Desa Purwosari Kecamatan Kandat dengan nama "Kusuma Bersaudara". Poklahsar ini mampu mengembangkan olahan abon ikan lele untuk dijadikan tumpuan ekonomi di daerahnya. Hal ini menunjukkan bahwa potensi industri pangan untuk olahan ikan lele bisa terus ditingkatkan, namun kondisi pasar yang semakin luas dan ketat menuntut untuk perbaikan mutu dan keamanan terhadap abon ikan lele. 
Berbagai produk hasil perikanan yang banyak dijumpai salah satunya adalah abon. Abon merupakan olahan daging yang mempunyai cita rasa yang khas karena menggunakan rempahrempah pilihan sebagai bumbu penyedapnya (Fachruddin 1997). Pembuatan abon dapat dijadikan salah satu alternatif pengolahan daging ikan lele. Menurut Suryani dkk. (2007) abon ikan merupakan jenis makanan olahan ikan yang diberi bumbu, diolah dengan cara perebusan dan penggorengan. Produk yang dihasilkan mempunyai bentuk lembut, rasa enak, bau khas, dan mempunyai daya simpan yang relatif lama.

Cara Produksi Pangan Olahan yang Baik (CPPOB) adalah pedoman yang digunakan untuk menjamin kegiatan produksi yang baik secara mutu ataupun keamanannya. Penerapan СРPOB perlu dilaksanakan di setiap unit pengolahan dari industri kecil hingga industri besar agar produk yang dihasilkan aman dan layak dikonsumsi. Pemerintah mengatur cara produksi pangan yang baik dalam Peraturan Menteri Perindustrian Nomor 75 Tahun 2010 tetang Pedoman Cara Produksi Pangan Olahan yang Baik (Good Manufacturing Practice). Peraturan ini dijadikan acuan umum bagi industri pengolahan pangan, pembina industri pengolahan pangan dan pengawas mutu atau keamanan pangan. $\mathrm{CPPOB}$ dapat dijadikan jaminan kualitas dan keamanan pangan bagi konsumen.

Poklahsar Kusuma Bersaudara mampu bersaing dengan industri lainnya dibidang makanan dengan meningkatkan kesadaran produsen dan karyawan mengenai pentingnya proses produksi yang baik dan bertanggung jawab terhadap produk abon ikan lele. Penerapan CPPOB merupakan indikator kemampuan produsen dan karyawan untuk memenuhi standar atau persyaratan yang ditetapkan untuk abon ikan lele.

Standar bagi produk hasil perikanan yang beredar di masyarakat seharusnya memenuhi standar yang berlaku di Indonesia. Standar berupa persyaratan mutu dan keamanan produk yang diatur oleh Badan Standar Nasional dalam bentuk Standar Nasional Indonesia (SNI). Standar ini merupakan acuan bagi produsen untuk menghasilkan produk yang sesuai dengan tuntutan konsumen.

Penelitian ini bertujuan untuk mempelajari penerapan CPPOB yang terdapat pada indutri rumah tangga pembuatan abon ikan lele di Desa Purwosari Kecamatan Kandat Kabupaten Kediri.

\section{METODE PENELITIAN}

\section{Waktu dan Tempat Penelitian}

Penelitian dilaksanakan di Desa Purwosari, Kecamatan Kandat, Kabupaten Kediri. Pengujian mikrobiologi dan kimia dilakukan di Laboratorium UPT Pengendalian dan Pengujian Mutu Hasil Perikanan Jawa Timur. Pengujian organoleptik dilaksanakan di Laboratorium UPT Pengendalian dan Pengujian Mutu Hasil Perikanan Jawa Timur. Waktu penelitian dilaksanakan pada Bulan Maret 2017.

\section{Metode Penelitian}

Metode penelitian yang dilakukan adalah metode survei. Penelitian dilakukan dengan mengamati secara langsung alur proses pembuatan dan penanganan abon ikan lele dari tahap penerimaan bahan hingga pemuatan Data yang diperoleh merupakan data primer dengan melakukan wawancara dan observasi lapangan terhadap pelaksanaan CPPOB dan pengujian secara organoleptik abon ikan lele. Data sekunder merupakan data uji mikrobiologis dan uji kimiawi abon ikan lele. Data dibandingkan dengan SNI 7690.2013 untuk spesifikasi, persyaratan bahan dan proses pengolahan tentang abon ikan.

\section{Alat dan Bahan}

Alat yang digunakan dalam pengamatan penerapan CPPOB adalah Lembar Petunjuk dan Tujuan Penanganan pada Alur Proses Pembuatan Abon Ikan SNI 7690.2013, termometer dan timer. Alat uji organoleptik adalah Lembar penilaian Organoleptik SNI 7690.2013, piring untuk wadah abon ikan lele dan sendok. Bahan yang digunakan adalah abon ikan lele dan hasil pengujian mikrobiologis dan kimiawi. 


\section{Prosedur Penelitian}

Prosedur penelitian yang dilakukan meliputi pengamatan penerapan Cara Produksi Pengolahan Pangan Olahan yang Baik, kemudian pengujian mikrobiologis, kimiawi dan organoleptik.

Analisis data dilakukan dengan analisis secara deskriptif komparatif. Menurut Nazir (2005), deskriptif komparatif adalah suatu metode dalam meneliti status suatu kelompok manusia, suatu obyek, suatu kondisi, suatu sistem pemikiran, ataupun suatu kelas peristiwa pada masa sekarang yang ingin mencari jawaban secara mendasar tentang sebab-akibat, dengan menganalisis faktor-faktor penyebab terjadinya. Data dianalisis dengan dibandingkan SNI 7690.2013 untuk spesifikasi, persyaratan bahan dan proses pengolahan tentang abon ikan.

\section{HASIL DAN PEMBAHASAN}

\section{Lokasi Produksi Abon Ikan Lele}

Produksi abon ikan lele dilakukan di rumah Bapak Syafrudin yang berada di Desa Purwosari Kecamatan Kandat Kabupaten Kediri. Produksi disesuaikan dengan kemampuan biaya dan pemberian rasa aman terhadap produsen. Dapur yang berada dibagian belakang rumah memiliki ukuran 8x10 m dan tinggi dinding 2,5 m. Dapur memiliki ventilasi berukuran 30x40 $\mathrm{cm}$ sebanyak dua buah dan tidak terdapat jendela. Fasilitas yang dimiliki ruang produksi menjadi bagian penting untuk memudahkan proses produksi yang aman dan nyaman (Junianto 2016).

Tempat produksi berada di perkampungan yang jauh dari pembuangan sampah, berpenduduk sedikit dan tidak kumuh, namun sekitar tempat produksi terdapat kolam ikan budidaya (Lampiran 4). Kolam ikan budidaya memiliki potensi bahaya terhadap lingkungan disekitarnya. Dampak yang timbul adalah pencemaran air akibat usaha budidaya (Nastiti dkk. 2001). Menurut Maniagasi dkk. (2013) potensi bahaya tersebut dapat dikendalikan jika pengendalian usaha budidaya tersebut dalam kondisi baik.

\section{Proses Pembuatan Abon Ikan Lele}

Berdasarkan SNI 7690.3:2013 pembuatan abon ikan dilakukan melalui proses penerimaan bahan baku, pencucian I, penyiangan, pencucian II, pengepresan, pengukusan, pencabikan, pencampuran, penggorengan, penirisan, pengemasan, penyimpanan, dan pemuatan, sedangakan proses pembuatan abon ikan lele tidak melakukan proses pengepresan. Hal ini dikarenakan produsen tidak memiliki alat pengepres. Setiap proses yang dilakukan memiliki tujuan dan maksud agar mutu abon yang didapat sesuai dengan syarat mutu (Tabel 1).

Penerimaan bahan adalah proses awal untuk memantau kualitas produk. Bahan yang digunakan diamati secara organoleptik dan disortir untuk mendapatkan bahan yang berkualitas baik. Bahan harus tetap dalam kondisi baik sampai saat dipergunakan (Sucipto 2015). Jenis bahan digolongkan kedalam bahan baku, bahan tambahan dan bahan penolong.

Bahan baku adalah ikan lele segar dan utuh, berat $\pm 1,5 \mathrm{~kg} / \mathrm{ekor}$ dan diutamakan yang berkelamin jantan. Ikan lele yang digunakan $\pm 45 \mathrm{~kg} /$ produksi. Bahan tambahan adalah bumbu dan minyak. Bumbu yang digunakan adalah bawang putih, gula, cabe, garam, jahe dan ketumbar. Persyaratan bumbu adalah bersih, tidak busuk dan utuh. Bahan tambahan adalah bumbu dan minyak. Bumbu yang digunakan adalah bawang putih, gula, cabe, garam, jahe dan ketumbar. Persyaratan bumbu adalah bersih, tidak busuk dan utuh. Bahan penolong adalah air, kemasan dan label. Air yang digunakan adalah air tanah yang disimpan di tandon agar terhindar bahan pencemar dari luar. Kemasan yang digunakan adalah kemasan alumunium foil pada bagian belakang dan plastik bening pada bagian depan. Kemasan berukuran $22 \times 14 \mathrm{~cm}$. Label yang digunakan adalah label yang sudah mencantumkan nama produk, berat bersih, daftar bahan yang digunakan, nama dan alamat produsen, dan tanggal kadaluarsa.

Pencucian dilakukan dengan membasuh ikan lele secara manual. Ikan lele yang masih segar dicuci mneggunakan air tanah yang mengalir selama \pm 20 detik/ ikan dengan suhu air $28^{\circ} \mathrm{C}$. Menurut Junianto (2003) penanganan ikan mati sebaiknya menggunakan suhu rendah karena akan memperlambat kemunduran mutu ikan. Menurut Purnawijayanti (2001), air tanah pada umumnya lebih bersih karena air yang belum terkontaminasi secara fisik, kimiawi dan mikrobiologis. 
Ikan lele yang sudah bersih dilakukan penyiangan untuk menghilangkan bagian kepala, insnag dan isi perut. Bagian ekor ikan tidak dipotong karena untuk mempersingkat waktu. Sisa penyiangan segera dibuang untuk melindungi ikan dari bakteri, serangga atau hewan penggerat (Purnawijayanti 2001).

Proses pengukusan dilakukan dengan menambahkan air sebanyak $1 / 4$ dari tinggi wadah pengukus $( \pm 10 \mathrm{~L})$. Pengukusan daging ikan lele pada suhu $\pm 95^{\circ} \mathrm{C}$ selama 3 jam. Suhu yang didapat adalah suhu daging pada bagian punggung ikan bagian atas tumpukan. Karakteristik daging yang telah matang adalah daging, duri dan kulit terpisah secara jelas dan warna agak kecoklatan.Setiap jam pengukusan dilakukan pemantauan secara fisik untuk mendapatkan hasil terbaik. Hal ini dikarenakan jika ikan kurang matang akan susah untuk memisahkan duri, kulit dan daging, sedangkan jika terlalu lama tekstur daging akan lembek. Daging yang lembek diakibatkan karena adanya kerusakan struktur jaringan protein (Purnawijayanti 2001). Menurut Sulthoniyah (2013) pengukusan lebih dari suhu $65^{\circ} \mathrm{C}$ menyebabkan kerusakan pada abon karena penggunaan suhu tinggi yang selanjutnya digoreng.

Pencabikan daging ikan lele dilakukan setelah memisahkan daging dari duri, sirip, kulit dan telur, mendapatkan tekstur yang homogen dan halus. Proses pencabikan juga dapat menghilangkan duri-duri halus yang masih ada dalam daging. Pencabikan mempengaruhi waktu pematangan dari abon (Sulthoniyah 2013).

Pencampuran dilakukan dengan mencampurkan daging ikan lele dengan bumbu yang dibersihkan dan dihaluskan. Bumbu yang digunakan adalah bawang putih $2 \%$ /daging lele, gula $15 \%$ /daging lele , cabe $0.01 \%$ /daging lele , garam 1,5\% /daging lele, jahe $0.01 \% /$ daging lele dan ketumbar 0,3\% /daging lele. Penghalusan bumbu menggunakan bantuan alat blender dan uleg-uleg.

Setiap 1,5 kg daging ikan lele yang sudah dicampur bumbu dilakukan penggorengan pada suhu minyak kurang dari $\pm 145^{\circ} \mathrm{C}$ selama 30 menit. Minyak goreng yang digunakan adalah minyak goreng komersil sebanyak 4 L. Setiap 3 kali penggorengan minyak dilakukan pergantian minyak karena kualitas minyak yang menurun. Penggorengan dilakukan dengan memanaskan minyak hingga suhu $\pm 100^{\circ} \mathrm{C}$, kemudian daging ikan yang sudah dicampur bumbu dimasukkan secara perlahan. Cara menggoreng adalah dengan memasukkan seluruh bahan ke dalam minyak (deep frying). Proses ini mengakibatkan abon mengandung banyak minyak.

Suhu penggorengan dipengaruhi oleh kandungan air pada bahan. Hal ini dikarenakan tingginya kandungan air pada bahan menyebabkan suhu penggorengan akan semakin lama untuk mencapai suhu tinggi (Gambar 1). Tingginya kadar air suatu bahan pada saat digoreng menyebabkan semakin banyak minyak yang dapat diserap. Kadar air daging ikan lele tergolong tinggi, karena tidak dilakukan proses pengurangan kadar air sebelum digoreng (pengepresan). Kadar air tinggi dan penggunaan suhu rendah pada proses penggorengan menyebabkan waktu penggorengan semakin lama, warna produk semakin terang dan minyak yang terserap lebih banyak (Hariyadi 2008).

Penirisan dilakukan setelah abon matang untuk menghilangkan kandungan minyak. Penirisan dilakukan dengan bantuan spinner. Menurut Wulandari dkk. (2009) prinsip utama mesin peniris minyak adalah mengurangi kandungan minyak bahan dengan menggunakan teknik putaran tinggi (sentrifus) sehingga mampu menarik minyak untuk keluar.

Pengemasan dilakukan menggunakan alat bantu heat sealer. Prinsip kerja pengemasan yaitu dengan merekatkan ujung terbuka kemasan abon menggunakan panas. Kemasan berisi 100 gram abon dan diberikan label.

Proses penyimpanan abon terdapat dalam dua bentuk, yaitu dalam kemasan dan dalam toples. Penyimpanan kemasan dilakukan jika abon siap untuk dikirim ke toko atau konsumen. Penyimpanan di toples sebagai stok untuk produsen jika ada pesanan mendadak. Hal ini dilakukan karena toples memiliki ukuran yang besar (volume $5 \mathrm{~L}$ ) dan dapat ditutup rapat.

Suhu penyimpanan merupakan faktor eksternal untuk pertumbuhan bakteri perusak ataupun patogen (Liviawaty 2010). Suhu penyimpanan abon ikan lele mencapai $33^{\circ} \mathrm{C}$ dan kelembaban udara 62\%, menurut Moutney dan Gould (1988) dalam Liviawaty (2010) suhu 30$40^{\circ} \mathrm{C}$ merupakan suhu optimum untuk pertumbuhan bakteri mesofilik (bakteri patogen dan non patogen) dan suhu minimum untuk bakteri termofilik (bakteri pembentuk spora dari tanah dan air). Kelembaban ruang yang berkisar antara $25-75 \%$ sangat mempengaruhi pertumbuhan spora jamur (Moerdjoko 2004). 
Penyimpanan makanan kering sebaiknya dilakukan dengan menjaga suhu kurang dari 220C, makanan disimpan dilemari dan tidak dilantai, serta lemari penyimpanan dibuat anti tikus dan serangga (Sucipto 2015). Menurut Moerdjoko (2004) pencemaran produk yang tidak tertutup berasal dari debu biogenik yaitu debu yang mengandung bakteri yang berupa tungau, jamur dan bakteri.

Pemuatan yang dilakukan oleh produsen abon ikan lele adalah menggunakan kardus. Pemilihan wadah pemuatan kardus karena mudah didapat, dapat menampung jumlah besar dan melindungi dari lingkungan.

\section{Hasil Pengujian Abon Ikan Lele}

Pengujian dilakukan dengan uji mikrobiologis, kimiawi dan uji organoleptik. Hasil pengujian dibandingkan dengan SNI 7690.1:2013 tentang spesifikasi abon ikan (Tabel 2). Tujuan pengujian adalah untuk mengetahui mutu abon ikan lele agar tidak membahayakan kesehatan manusia.

Nilai mutu spesifikasi SNI 7690:2013 minimal 7 dan pengujian organoleptik menunjukkan bahwa nilai abon ikan lele adalah 7,2. Abon ikan lele memiliki kenampakan warna coklat cemerlang dan serat kurang homogen, bau abon ikan kurang kuat, rasa ikan lele yang cukup terasa dan memiliki tekstur kering agak menggumpal.

Pengujian mikrobiologis dilakukan dengan menguji ALT Aerob, E. coli, Staphyloccocus aureus dan Salmonella. Hasil menunjukkan bahwa jumlah bakteri ALT Aerob pada abon ikan sebanyak $1.7 \times 10^{2}$ Koloni/g , tidak melewati batas maksimal $5 \times 10^{5} \mathrm{Koloni} / \mathrm{g}$, Jumlah bakteri $E$. coli tidak lebih dari $3 \mathrm{APM} / \mathrm{g}$ dan bakteri Staphylococcus aureus kurang dari 10 koloni/g. Bakteri Salmonella dalam abon ikan dinyatakan negatif. Tujuan utama pengamatan mikrobiologis adalah memberikan kualitas terhadap kebersihan penanganan dan pengoalahan, serta kemungkinanan adanya bakteri berbahaya (Liviawaty 2010).

Hasil menunjukkan bahwa kadar air abon ikan lele sebesar 4,83\% dengan maksimal kadar air sebesar $15 \%$. Kadar air pada produk yang disimpan berperan penting bagi perkembangan hama (Sucipto 2015). Menurut Sunarya (2014), manipulasi kadar air penting untuk menjaga mutu dan pengawetan makanan. Kandungan protein abon ikan lele mencapai 40,55\% menunjukkan bahwa abon melebihi batas minimal protein sebesar 30\%. Peningkatan kadar protein disebabkan karena turunnya kadar air dalam abon ikan akibat pengolahan. Hal ini menyebabkan kandungan protein meningkat padahal kadar protein mengalami penrunan akibat proses pengolahan (Sulthoniyah 2013). 
Tabel 1. Pelaksanaan dan Perbandingan Proses Pembuatan Abon Ikan Lele dengan SNI 7690:2013.

\begin{tabular}{|c|c|c|c|c|}
\hline No. & Alur Proses & $\begin{array}{c}\text { Pelaksanaan Proses } \\
\text { Produksi }\end{array}$ & Mutu Tahapan Produksi & $\begin{array}{c}\text { Syarat Mutu (SNI } \\
7690: 2013)\end{array}$ \\
\hline 1 & $\begin{array}{l}\text { Penerimaan } \\
\text { Bahan }\end{array}$ & $\begin{array}{l}\text { Menyeleksi, menimbang, } \\
\text { dan membedakan sesuai } \\
\text { jenis bahan } \\
\text { Bahan baku dimatikan } \\
\text { dengan memukul kepala } \\
\text { sebelum proses produksi } \\
\text { dimulai. } \\
\text { Bahan tambahan adalah } \\
\text { bumbu dan minyak. Bumbu } \\
\text { dicuci dan dihaluskan untuk } \\
\text { persiapan proses } \\
\text { pencampuran dengan daging } \\
\text { ikan lele. Minyak adalah } \\
\text { minyak goreng komersil. } \\
\text { Bahan penolong adalah air, } \\
\text { kemasan dan label yang } \\
\text { dilakukan pengecekan } \\
\text { secara visual pan }\end{array}$ & $\begin{array}{l}\text { Bahan baku adalah ikan } \\
\text { lele segar dan utuh, } \\
\text { berat } \pm 1,5 \mathrm{~kg} / \mathrm{ek} \text { dor dan } \\
\text { diutamakan yang } \\
\text { berkelamin jantan. } \\
\text { Persyaratan bumbu } \\
\text { adalah bersih, tidak } \\
\text { busuk dan utuh. } \\
\text { Minyak } \\
\text { dipantau goreng } \\
\text { kadaluarsa dan kondisi } \\
\text { dari kemasan yang } \\
\text { digunakan. } \\
\text { Air yang digunakan } \\
\text { memenuhi persyaratan } \\
\text { tidak berbau, tidak } \\
\text { berwarna dan tidak } \\
\text { berasa. Kemasan yang } \\
\text { digunakan adalah } \\
\text { kemasan alumunium } \\
\text { foil pada bagian } \\
\text { belakang dan plastik } \\
\text { bening pada bagian } \\
\text { depan. Label yang } \\
\text { digunakan adalah label } \\
\text { yang } \\
\text { mencantumkan nadah } \\
\text { produk, berat bersiha } \\
\text { komposisi bahan, nama } \\
\text { dan alamat produsen, } \\
\text { sertifikat halal, izin } \\
\text { produksi, dan tangal } \\
\text { kadaluarsa }\end{array}$ & $\begin{array}{l}\text { Bahan sesuai } \\
\text { spesifikasi mutu dan } \\
\text { keamanan pangan } \\
\text { Bahsn baku semua } \\
\text { jenis ikan dan dalam } \\
\text { kondisi } \\
\text { utuh/fillet. } \\
\text { Bahan tambar, } \\
\text { bumbu dalam kondisi } \\
\text { segar dan utuh. Minyak } \\
\text { sesuai dengan SNI 01- } \\
\text { 3741-2002 tentang } \\
\text { Minyak Goreng. } \\
\text { Bahan penolong air } \\
\text { adalah air yang sesuai } \\
\text { dnegan persyaratan air } \\
\text { minum. Penggunaan es } \\
\text { sesuai SNI 01-4872.1- } \\
\text { 2006 tentang Es untuk } \\
\text { Penanganan Ikan } \\
\text { Kemasan yang } \\
\text { digunakan adalah } \\
\text { kemasan untuk pangan, } \\
\text { tidak mencemari } \\
\text { produk, dan bersih. } \\
\text { Label mendapatkan } \\
\text { spesifikasi untuk } \\
\text { pangan, minimal } \\
\text { mencantumkan nama } \\
\text { produk, berat bersih, } \\
\text { daftar bahan yang } \\
\text { digunakan, nama dan } \\
\text { alamat produsen, } \\
\text { tanggal, bulan dan } \\
\text { tahun produksi untuk } \\
\text { produksi dan } \\
\text { kadaluarsa }\end{array}$ \\
\hline 2 & Pencucian I & 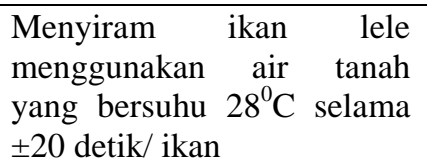 & $\begin{array}{l}\text { Ikan lele sudah terlihat } \\
\text { hilang kotoran dan } \\
\text { lendir yang menempel } \\
\text { pada kulit. }\end{array}$ & $\begin{array}{lr}\text { Mendapatkan ran } \\
\text { yang bersih dan } \\
\text { menghindari } \\
\text { kemunduran mutu }\end{array}$ \\
\hline 3 & Penyiangan & $\begin{array}{l}\text { Menghilangkan bagian yang } \\
\text { tidak digunakan. }\end{array}$ & $\begin{array}{l}\text { Ikan hilang } \text { bagian } \\
\text { kepala, insang dan isi } \\
\text { perut }\end{array}$ & $\begin{array}{lr}\text { Ikan tanpa } & \text { kepala, } \\
\text { indang, isi } & \text { perut dan } \\
\text { ekor serta } & \text { mereduksi } \\
\text { kontaminasi } & \text { bakteri } \\
\text { patogen. } & \end{array}$ \\
\hline 4 & Pencucian II & $\begin{array}{l}\text { Menyiram ikan dengan air } \\
\text { mengalir selama } \pm 30 \text { detik/ } \\
\text { ikan sampai ikan bersih }\end{array}$ & $\begin{array}{l}\text { Ikan bersih ketika tidak } \\
\text { ada darah yang } \\
\text { menempel. }\end{array}$ & $\begin{array}{lr}\text { Mendapatkan ikan } \\
\text { yang bersih dan } \\
\text { menghindari } \\
\text { kemunduran mutu. }\end{array}$ \\
\hline
\end{tabular}

\begin{tabular}{llllll}
\hline 5 & Pengukusan & $\begin{array}{l}\text { Dikukus secara langsung } \\
\text { dengan suhu } \pm 95^{\circ} \mathrm{C} \text { selama } \\
\pm 3 \text { jam }\end{array}$ & $\begin{array}{l}\text { Daging yang telah } \\
\text { matang adalah daging, } \\
\text { duri dan kulit terpisah } \\
\text { secara jelas dan warna } \\
\text { agak kecoklatan. }\end{array}$ & $\begin{array}{l}\text { kemanan yang sesuai. } \\
\text { ikangan }\end{array}$ \\
\hline 6 & Pengepresan & Tidak dilakukan & & $\begin{array}{l}\text { Kandungan air dalam } \\
\text { daging ikan berkurang. }\end{array}$ \\
\hline
\end{tabular}




\begin{tabular}{|c|c|c|c|c|}
\hline 7 & Pencabikan & $\begin{array}{l}\text { Dicabik menggunakan } \\
\text { tangan dan dibersihkan dari } \\
\text { yang masih menempel } \\
\text { dalam daging }\end{array}$ & $\begin{array}{l}\text { Daging ikan lele } \\
\text { dengan tekstur yang } \\
\text { homogen dan halus. }\end{array}$ & $\begin{array}{l}\text { Mendapatkan bentuk } \\
\text { daging yang homogen. }\end{array}$ \\
\hline 8 & Pencampuran & $\begin{array}{l}\text { Bumbu dicuci dan } \\
\text { dihaluskan dan dicampurkan } \\
\text { sedikit demi sedikit dengan } \\
\text { daging ikan }\end{array}$ & $\begin{array}{l}\text { daging ikan dan bumbu } \\
\text { terlihat merata. }\end{array}$ & $\begin{array}{l}\text { Mendapatkan daging } \\
\text { ikan yang tecampur } \\
\text { dengan bumbu secara } \\
\text { homogen. }\end{array}$ \\
\hline 9 & Penggorengan & $\begin{array}{l}\text { Digoreng dengan suhu suhu } \\
\text { minyak kurang dari } \pm 145^{\circ} \mathrm{C} \\
\text { selama } 30 \text { menit }\end{array}$ & $\begin{array}{l}\text { Penggorengan sampai } \\
\text { daging menjadi abon } \\
\text { yang berwarna coklat } \\
\text { terang. }\end{array}$ & $\begin{array}{lr}\text { Mendapatkan abon } \\
\text { yang berwarna } & \text { coklat } \\
\text { spesifik dan sangat } \\
\text { cemerlang. }\end{array}$ \\
\hline 10 & Penirisan & $\begin{array}{l}\text { Penirisan dengan alat } \\
\text { spinner sistem sentrifugal } \\
\text { selama } 2 \text { menit sebanyak } 3 \\
\text { kali }\end{array}$ & $\begin{array}{lr}\text { Abon memiliki tekstur } \\
\text { yang kering } \\
\text { menggumpal. }\end{array}$ & $\begin{array}{l}\text { Mendapatkan mutu } \\
\text { abon yang kering dan } \\
\text { tidak menggumpal. }\end{array}$ \\
\hline 11 & Pengemasan & $\begin{array}{l}\text { Menggunakan kemasan dan } \\
\text { dengan alat heat selaer }\end{array}$ & $\begin{array}{l}\text { Abon tidak rusak saat } \\
\text { disimpan }\end{array}$ & $\begin{array}{l}\text { Mendapatkan produk } \\
\text { yang aman dikonsumsi } \\
\text { dan melindungi produk } \\
\text { selama penyimpanan } \\
\text { dan pemuatan. }\end{array}$ \\
\hline 12 & Penyimpanan & $\begin{array}{l}\text { Penyimpanan pada suhu } \\
33^{\circ} \mathrm{C} \text { dan menggunakan } \\
\text { sistem FIFO }\end{array}$ & $\begin{array}{l}\text { Abon tidak rusak dan } \\
\text { tahan lama. }\end{array}$ & $\begin{array}{l}\text { Mendapatkan produk } \\
\text { yang aman dikonsumsi } \\
\text { dan melindungi produk } \\
\text { selama penyimpanan }\end{array}$ \\
\hline 13 & Pemuatan & Menggunakan kardus & $\begin{array}{l}\text { Melindungi abon dari } \\
\text { kerusakan. }\end{array}$ & $\begin{array}{l}\text { Mendapatkan produk } \\
\text { yang aman dikonsumsi } \\
\text { dan melindungi produk } \\
\text { selama pemuatan. }\end{array}$ \\
\hline
\end{tabular}

Tabel 2. Hasil Pengujian Abon Ikan Lele dengan SNI 7690.1:2013.

\begin{tabular}{cccc}
\hline Parameter Uji & Batas Standar & Hasil Uji & Satuan \\
\hline Organoleptik & & & \\
\hline Sensori & 7 & 7,2 & \\
\hline Mikrobiologis & & & \\
\hline ALT Aerob & Maksimal 5 x 10 & $1.7 \times 10^{2}$ & Koloni/g \\
\hline E. coli & $<3$ & $<3$ & APM/g \\
\hline Staphyloccocus aureus & Maksimal 1,0 x 10 & $<10$ & Koloni/g \\
\hline Salmonella & Negatif & Negatif & / 25 g \\
\hline Kadar air & & & $\%$ \\
\hline Kadar protein & Maksimal 15 & 4.83 & $\%$ \\
\hline
\end{tabular}

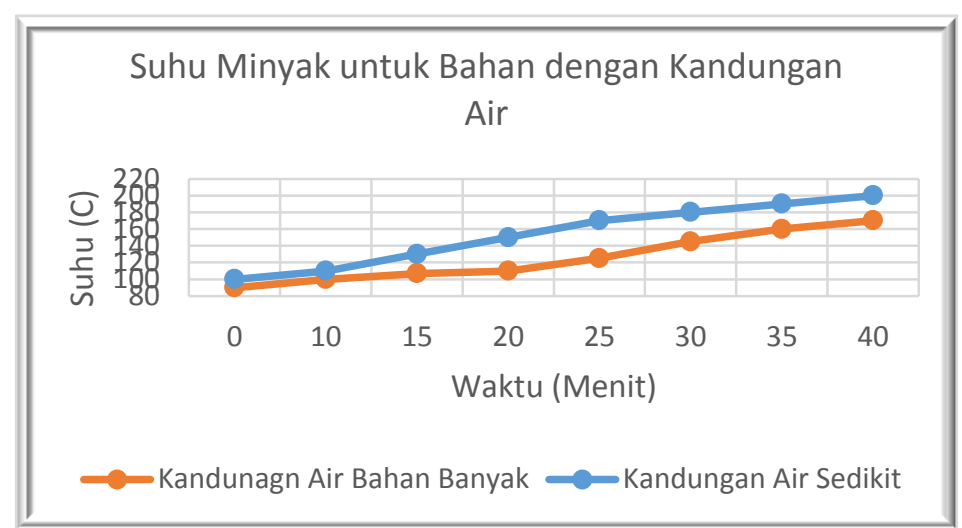

Gambar 1. Suhu Minyak untuk Kanudngan Air (Sumber: Hariyadi 2008) 


\section{KESIMPULAN}

Pengawasan bahan abon ikan lele dilaksanakan dengan baik dan memperhatikan persyaratan mutu bahan abon. Proses produksi abon ikan lele yang tidak melakukan pengepresan menunjukkan proses produksi belum efisien. Akan tetapi, dengan hasil pengujian laboratorium abon ikan lele sesuai dengan spesifikasi SNI Abon Ikan. Hal ini menunjukkan bahwa produk aman dan layak untuk dikonsumsi, akan tetapi perlu adanya perbaikan dalam proses produksi.

\section{REKOMENDASI}

Salah satu tujuan dari penerapan Cara Produksi Pangan Olahan yang Baik adalah agar tercapainya efisiensi produksi. Produsen abon ikan lele perlu untuk melakukan proses pengepresan agar sesuai dengan standar dan meningkatkan pendapatan.

\section{DAFTAR PUSTAKA}

Badan Standarisasi Nasional (BSN). 2013. SNI 7690:2013. Abon Ikan. Jakarta. Fachruddin, L. 1997. Membuat Aneka Abon. Kanisius. Yogyakarta.

Hariyadi, P. 2008. Teknologi Penggorengan. Food Review Indonesia, 3 (3). April 2008. Junianto 2016. Manajemen Industri Hasil Perikanan. Unpad Press. Sumedang Junianto. 2003. Teknik Penanganan Ikan. Penebar Swadaya. Jakarta.

Liviawaty, E. dan E. Afrianto. 2010. Penangann Ikan Segar. Widya Padjajaran. Bandung.

Maniagasi, R., S. Sipriana, Tumembouw dan M. Yoppy. 2013. Analisis Kualitas Fisika Kimia Air di Areal Budidaya Ikan Danau Tondano Provinsi Sulawesi Utara. Jurnal Budidaya Perairan.1 (2).

Moerdjoko. 2004. Kaitan Sistem Ventllasi Bangunan dengan Keberadaan Mikroorganisme Udara. Fakultas Teknik Sipil dan Perencanaan. Universitas Kristen Petra

Nastiti, A.S., S.Nuroriah dan S.E. Purnamaningtyas. 2001. Dampak Budidaya Ikan dalam Jaring Apung terhadap Peningkatan Unsur N dan P di Perairan Waduk Saguling, Cirata dan Jatiluhur. Jurnal Penelitian Perikanan.

Nazir, M. 2005, Desain Penelitian, Cetakan ke dua. Penerbit Erlangga. Jakarta

Purnawijayanti, A. H. 2001. Sanitasi, Higiene dan Keselamatan Kerja dalam Pengolahan Makanan. Kanisius. Yogyakarta.

Sucipto, C. D. 2015. Keamanan Pangan untuk Kesehatan Manusia. Gosyen Publishing. Yogyakarta.

Sulthoniyah, S. T. M., T. D. Sulistiyati dan E. Suprayitno. 2013. Pengaruh Suhu Pengukusan Terhadap Kandungan Gizi dan Organoleptik Abon Ikan Gabus (Ophiocephalus striatus). THPi Student Journal. I (1): 33-45

Sunarya. 2014. Mutu dan Keamanan Pangan Hasil Perikanan. CV. The Spring. Bogor.

Suryani, A., E. Hambali dan E. Hidayat. 2007. Membuat Aneka Abon. Penebar Swadaya. Jakarta. Wulandari, A. dan S. R. Nunuk. 2009. Perbaikan Teknik Pembuatan Keripik Menggunakan Penirisan Minyak di Sentra Industri Makanan Ringan Dusun Jiwan, Gondangan, Jogonalan, Klaten. Jurnal Prospect Februari 2009, Tahun 5 Nomor 8. Hal 39-44. 